\title{
INFLUENCE ANALYSIS OF BI RATE, INFLATION AND IHSG ON STOCK RETURN OF BANKING SECTOR LISTED ON INDONESIAN STOCK EXCHANGE
}

\author{
Ferry Suwito \\ Sekolah Tinggi Ilmu Ekonomi Wiyatamandala \\ someriff@gmail.com
}

\begin{abstract}
This research aims to prove if there is any effect from the change of BI Rate, inflation, and IHSG to the return of banking sector listed in Indonesian Stock Exchange. Hypothesis is tested using multiple regression linear with monthly observation period during year 2007 - 2011 towards 12 banking stock return which are listed in Indonesia Stock Exchange. This research provides empirical evidence that simultaneously BI Rate, inflation and IHSG have effect on 9 stock return of banking sector, whereas partially tested IHSG has the most significant effect on stock return on banking companies compared with BI rate and inflation.
\end{abstract}

Key words: BI Rate, inflation, IHSG, Return

\section{PENDAHULUAN}

Pasar modal adalah salah satu sarana untuk menghimpun sumber dana ekonomi jangka panjang yang tersedia di perbankan dan masyarakat. Sebagai bagian dari sistem perekonomian suatu negara, khususnya dalam sektor keuangan, pasar modal menyediakan dua fungsi pokok bagi masyarakat yang masing-masing memiliki kepentingan yang berbeda, yaitu sebagai fungsi ekonomi dan keuangan. Dalam melaksanakan fungsi ekonominya, pasar modal menyediakan fasilitas untuk memindahan dana dari pihak yang mempunyai kelebihan dana (investor) kepada pihak yang memerlukan dana (emiten). Dengan menginvestasikan kelebihan dana yang mereka miliki, penyandang dana berharap akan memperoleh imbalan dari penyerahan dana tersebut. Bagi peminjam dana, tersedianya dana tersebut pada pasar modal memungkinkan mereka untuk melakukan kegiatan usaha tanpa harus menunggu dana yang mereka peroleh dari hasil operasi perusahaannya. Proses semacam ini diharapkan mampu meningkatkan produktivitas perusahaan, 
yang akhirnya mampu meningkatkan kemampuan dan kesejahteraan suatu negara (Haruman, 2006). Di dalam teori investasi dikatakan bahwa setiap sekuritas akan menghasilkan return dan risiko. Return merupakan tingkat pengembalian dari nilai investasi yang diserahkan oleh investor, sedangkan risiko adalah perbedaan return yang diharapkan dengan return yang terealisasi dari sekuritas tersebut. Return tinggi seringkali disertai dengan risiko yang tinggi dan return yang rendah akan mempunyai risiko yang rendah juga (Haryanto dan Riyatno, 2007). Perekonomian Indonesia pada tahun 2011 menunjukkan daya tahan yang kuat di tengah meningkatnya ketidakpastian ekonomi global, tercermin pada kinerja pertumbuhan yang bahkan lebih baik dan kestabilan makroekonomi yang tetap terjaga. Pertumbuhan ekonomi Indonesia mencapai $6,5 \%$, angka tertinggi dalam sepuluh tahun terakhir, disertai dengan pencapaian inflasi pada tingkat yang rendah sebesar 3,79\%. Di sektor keuangan, stabilitas sistem keuangan tetap terjaga meski sempat terjadi tekanan di pasar keuangan pada semester II tahun 2011 sebagai dampak memburuknya krisis yang terjadi di kawasan Eropa dan Amerika Serikat (AS). Dengan ketahanan ekonomi yang kuat dan risiko utang luar negeri yang rendah, didukung oleh kebijakan makroekonomi yang tetap dan berbagai langkah kebijakan struktural yang terus ditempuh selama ini, Indonesia kembali memperoleh peningkatan peringkat menjadi Investment grade. Ketidakpastian yang muncul akibat krisis utang Eropa dan kekhawatiran terhadap prospek pemulihan perekonomian AS telah memicu gejolak di pasar keuangan dan pelemahan pertumbuhan ekonomi global pada tahun 2011. Dampak dari gejolak global tersebut ke Indonesia lebih banyak dirasakan di pasar keuangan terutama pasar modal, sementara dampak pada sektor riil relatif minimal. Di sektor keuangan, penarikan modal luar negeri oleh sebagian investor pada semester II tahun 2011 memberikan tekanan pada nilai tukar rupiah, imbal hasil obligasi pemerintah, dan harga saham. Namun, dengan langkah-langkah stabilisasi oleh Bank Indonesia dan pemerintah, serta didukung oleh kuatnya fundamental sektor keuangan dan terjaganya stabilitas makroekonomi, gejolak pasar keuangan dapat dihindari (Laporan Tahunan Bank Indonesia 2011). 
Berdasarkan latar belakang di atas dapat dirumuskan permasalahan sebagai berikut :

1. Apakah BI Rate berpengaruh terhadap return saham sektor perbankan periode 2007 2011 ?

2. Apakah inflasi berpengaruh terhadap return saham sektor perbankan periode 2007 $2011 ?$

3. Apakah IHSG berpengaruh terhadap return saham sektor

\section{TELAAH LITERATUR}

BI Rate

Definisi BI Rate menurut website Bank Indonesia adalah suku bunga kebijakan yang mencerminkan sikap atau stance kebijakan moneter yang ditetapkan oleh bank Indonesia dan diumumkan kepada publik (BI, 2010). Menurut Bernanke dan Kuttner (2004) perubahan dalam kebijakan moneter memiliki pengaruh terhadap perubahan harga saham dimana tujuan kebijakan moneter terlihat dari variabel makroekonomi yang dihasilkan seperti perubahan suku bunga bank sentral yang dapat mempengaruhi pasar keuangan dan merupakan hal yang penting untuk mengerti mekanisme perubahan perbankan periode 2007 2011 ?

4. Variabel mana yang paling mempengaruhi return saham sektor perbankan periode 2007 -2011 ?

5. Bagaimana pengaruh $\mathrm{BI}$ rate, inflasi dan IHSG secara simultan terhadap return saham sektor perbankan yang terdaftar di Bursa Efek Indonesia periode 2007 - 2011 ? kebijakan moneter tersebut terhadap pasar modal. Sedangkan Beirne et al. (2009) melakukan penelitian terhadap faktor yang mempengaruhi return saham dan menunjukkan suku bunga bank sentral tidak memiliki pengaruh terhadap return saham perbankan dan jasa keuangan namun tidak memiliki pengaruh terhadap saham sektor asuransi. BI Rate diumumkan oleh Dewan Gubernur Bank Indonesia setiap Rapat Dewan Gubernur bulanan dan diimplementasikan pada operasi moneter yang dilakukan Bank Indonesia melalui pengelolaan likuiditas (liquidity management) di pasar uang untuk mencapai sasaran operasional kebijakan 
moneter. Sasaran operasional kebijakan moneter dicerminkan pada perkembangan suku bunga Pasar Uang Antar Bank Overnight (PUAB O/N). Pergerakan di suku bunga PUAB ini diharapkan akan diikuti oleh perkembangan di suku bunga deposito, dan pada gilirannya suku bunga kredit perbankan. Dengan mempertimbangkan pula faktor-faktor lain dalam perekonomian, Bank Indonesia pada umumnya akan menaikkan BI Rate apabila inflasi ke depan diperkirakan melampaui sasaran yang telah ditetapkan, sebaliknya Bank Indonesia akan menurunkan BI Rate apabila inflasi ke depan diperkirakan berada di bawah sasaran yang telah ditetapkan.

Inflasi

Menurut Mousa et al. (2012) mendefinisikan inflasi sebagai kenaikan harga dari semua barang dan jasa, dan merupakan peningkatan yang permanen yang menyebabkan melemahnya daya beli dan meningkatnya cost of living selain itu juga dianggap sebagai fenomena yang menarik perhatian di negara maju maupun negara berkembang Hal ini akan membawa dampak perubahan harga saham tersebut dalam penelitian yang dilakukannya faktor inflasi yang tinggi juga berpengaruh terhadap harga suatu saham selain itu inflasi akan menurunkan menurunkan daya beli dan menyebabkan penurunan nilai asset perusahaan. Iqbal dan Haider (2005) melakukan penelitian terhadap Karachi Stock Exchange and the general market index (KSE-100), dengan 24 saham pilihan yang merupakan saham-saham yang paling aktif dengan nilai kapitalisasi mencapai $80 \%$ keseluruhan indeks. Mereka menemukan bahwa salah satu faktor makroekonomi yang signifikan mempengaruhi imbal hasil saham adalah inflasi dan indeks harga saham gabungan.

Menurut Montagnoli (2006) di saat terjadi kenaikan harga barang perubahan maka terjadi inflasi tingkat perubahan inflasi yang dapat menimbulkan pengaruh terhadap perubahan harga saham.

Menurut McTaggart, Findlay, dan Parkin (2003) dilihat dari penyebabnya, maka inflasi dapat dibedakan menjadi dua, yaitu:

\section{Demand-pull inflation}

Inflasi ini disebabkan oleh kenaikan dari pengumpulan permintaan

(Aggregate 
demand). Faktor-faktor yang dapat menyebabkan terjadinya inflasi seperti ini adalah peningkatan persediaan uang yang beredar, peningkatan pembelanjaan negara, peningkatan harga barang dalam negeri terhadap barang impor.

2. Cost - push inflation

Inflasi ini disebabkan oleh meningkatnya biaya. Ada dua hal yang dapat menyebabkan inflasi seperti ini, yaitu peningkatan kenaikan upah dan peningkatan harga barang baku produksi.

Saham

Saham adalah bukti penyertaan modal dalam suatu kepemilikan di perusahaan. Saham terbagi menjadi dua jenis, yaitu saham biasa (common stock) dan saham preferen (preferred stock) (Makaryanawati dan Ulum, 2009). Menurut Rahardjo (2006) dalam Makaryanawati dan Ulum (2009) investor yang memiliki saham, baik saham biasa maupun saham preferen akan mendapatkan bagian keuntungan yang diperoleh dari perusahaan dalam bentuk dividen. Pembagian dividen oleh perusahaan akan dilakukan apabila kinerja keuangan perusahaan bagus dan dapat melunasi kewajiban keuangannya. Menurut Darmadji dan Fakhruddin (2001) beberapa karakteristik yuridis kepemilikan saham suatu perusahaan, antara lain:

1. Limited Risk, artinya pemegang saham hanya bertanggung jawab sampai jumlah yang disetorkan ke dalam perusahaan.

2. Ultimate Control, artinya pemegang saham (secara kolektif) akan menentukan arah dan tujuan perusahaan.

3. Residual Claim, artinya pemegang saham merupakan pihak terakhir yang mendapat pembagian hasil usaha perusahaan (dalam bentuk dividen) dan sisa aset dalam proses likuidasi perusahaan. Pemegang saham memiliki posisi yunior dibanding pemegang obligasi atau kreditor.

\section{Indeks Harga Saham}

Indeks harga saham adalah indikator atau cerminan pergerakan harga saham. Indeks merupakan salah satu pedoman 
bagi investor untuk melakukan investasi di pasar modal, khususnya saham dan juga dapat dijadikan sebagai salah satu pengukuran untuk melihat kinerja suatu bursa (Bodie, Kane, dan Marcus, 2011). Respon pasar modal atas berbagai faktor ekonomi makro tercermin dari harga saham, dimana pergerakannya bisa terlihat dari Indeks Harga Saham Gabungan (IHSG). IHSG ini merupakan suatu indikator naik turunnya kegiatan pasar modal di Bursa Efek Indonesia (BEI) karena merupakan gabungan (composite) atas seluruh harga saham biasa maupun saham preferen yang tercatat di Bursa Efek Indonesia. Pergerakan indeks menjadi indikator pernting bagi para investor untuk menentukan apakah mereka akan menjual, menahan atau membeli sesuatu atau beberapa saham. Karena harga harga saham akan bergerak dalam hitungan detik dan menit, maka nilai indeks pun bergerak turun naik dalam hitungan waktu yang cepat pula. Masyarakat luas dapat mengamati pergerakan harga saham tertentu maupun IHSG setiap saat dengan mudah langsung di bursa, atau melalui situs resmi BEI (Martini, 2009).
Faktor yang mempengaruhi harga Saham

Menurut Weston dan Brigham (2008), faktor-faktor yang mempengaruhi harga saham yaitu :

1. Earnings per Share (EPS)

$\begin{array}{lcc}\text { Seorang } & \text { investor } & \text { yang } \\ \text { melakukan } & \text { investasi } & \text { pada } \\ \text { perusahaan } & \text { yang } & \text { akan }\end{array}$
menerima laba atas saham yang dimilikinya. Semakin tinggi laba per lembar saham yang diberikan perusahaan maka para investor akan semakin percaya bahwa perusahaan akan memberikan pengembalian yang cukup baik. Ini akan mendorong investor untuk melakukan investasi yang lebih besar lagi sehingga harga saham perusahaan akan meningkat.

2. Tingkat Bunga

Tingkat bunga dapat mempengaruhi harga saham dengan cara:

Mempengaruhi persaingan di pasar modal antara saham dan obligasi, apabila suku bunga naik maka investor akan mendapatkan hasil yang lebih besar dari obligasi, sehingga 
mereka akan segera menjual saham mereka untuk ditukarkan dengan obligasi. Penukaran yang demikian akan menurunkan harga saham. Hal ini sebaliknya juga terjadi apabila tingkat bunga mengalami penurunan.

3. Jumlah dividen kas yang diberikan Kebijakan keuntungan perusahaan dibagi menjadi dua, yaitu sebagian dibagikan dalam bentuk dividen dan sebagian lagi disisihkan sebagai laba ditahan. Sebagai salah satu faktor yang mempengaruhi harga saham, maka peningkatan pembagian dividen merupakan salah satu cara untuk meningkatkan kepercayaan dari pemegang saham karena jumlah kas dividen yang besar adalah yang diinginkan oleh investor sehingga harga saham meningkat.

4. Tingkat risiko dan tingkat pengembalian (Risk and Return)

Apabila tingkat risiko dari proyeksi laba yang diharapkan perusahaan meningkat maka akan mempengaruhi harga perusahaan. Biasanya semakin tinggi risiko semakin besar tingkat pengembalian (High risk high return) yang diharapkan investor. Hal ini akan mempunyai pengaruh yang besar antara sikap para investor dengan tingkat harga saham yang diharapkan.

Menurut Sofyan (2000), terdapat faktorfaktor eksternal yang mempengaruhi harga saham, yaitu:

1.Kebijakan pemerintahan dan dampaknya

Kebijakan pemerintah yang berkaitan langsung dengan bidang bisnis perusahaan emiten sangat berpengaruh terhadap harga saham. Misalnya kebijakan akan pembatalan pada proyek-proyek pemerintah, swastanisasi perusahaan negara, pembukaan keran bagi investor asing di sektor-sektor tertentu.

2. Pergerakan suku bunga Tingginya suku bunga merupakan pukulan bagi industri jasa perbankan. Akibat suku bunga 
yang meningkat tajam, proporsi operating leverage pada banyak emiten mengalami peningkatan yang cukup signifikan. Bagi perusahaan perbankan, meningkatnya suku bunga BI tidak hanya memberikan peluang pendapatan dari simpanannya di bank sentral, tetapi juga merupakan faktor yang menaikan biaya usaha. Dengan kenaikan tingkat suku bunga $\mathrm{BI}$, bank sulit untuk tidak menaikan suku bunga depositonya. Maka suku bunga kredit tinggi. Tingginya suku bunga juga merupakan pukulan bagi emiten yang bergerak di sektor properti. Proyek properti bersifat jangka

\section{METODOLOGI PENELITIAN}

Data yang digunakan dalam penelitian adalah data sekunder, yaitu data historis yang tersedia di Bursa Efek Indonesia, dan Bank Indonesia yaitu :

1 Return saham perbankan selama lima periode yaitu 2007 - 2011, data dapat diperoleh dari Yahoo!

Finance.

2 BI Rate selama lima periode yaitu 2007 - 2011, data panjang, dengan kontrak bunga yang tidak seluruhnya ditetapkan secara flat. Ketika suku bunga perbankan amat tinggi, perusahaan properti mengalami kesulitan yang lebih besar untuk mengembalikan pinjamannya.

3. Rumor dan sentimen pasar

Rumor dan sentimen pasar merupakan variabel bersifat intangible. Rumor sering muncul di BEI, misalnya gosip likuidasi bank, isu meninggalnya pejabat. Sedangkan sentimen pasar terbentuk oleh pemicu seperti pernyataan pejabat tertentu.

dapat diperoleh dari Bank Indonesia.

3 Tingkat Inflasi selama lima periode yaitu 2007 - 2011, data dapat diperoleh dari Biro Pusat Statistik.

4 IHSG selama lima periode yaitu 2007 - 2011, data dapat diperoleh dari Yahoo! Finance.

Dalam penelitian ini akan diamati kinerja saham sektor perbankan yang 
tercatat di Bursa Efek Indonesia pada periode yang telah ditentukan sebagai periode pengamatan yaitu tahun 20072011. Kinerja saham-saham tersebut diukur berdasarkan tingkat pengembalian (rate of return) dari masing-masing saham sektor perbankan yang telah dipilih untuk digunakan dalam penelitian ini dihitung dengan menggunakan rumus:

$$
\mathrm{R}_{\mathrm{i}, \mathrm{t}}=\mathrm{P}_{\mathrm{i}, \mathrm{t}}-\mathrm{P}_{\mathrm{i}, \mathrm{t}-1}
$$

Yaitu di mana:

$\mathrm{Ri}, \mathrm{t}=$ return saham individual $\mathrm{i}$ pada perode $\mathrm{t}$

$\mathrm{P} \mathrm{i}, \mathrm{t}=$ harga saham ke $\mathrm{i}$ pada periode $\mathrm{t}$

$\mathrm{P} \mathrm{i}, \mathrm{t}-1$ = harga saham ke $\mathrm{i}$ pada periode $\mathrm{t}-1$

Dalam penelitian ini akan diamati perubahan indikator-indikator moneter yang telah ditentukan yaitu BI Rate, inflasi, dan IHSG. Periode pengamatan yang dilakukan terhadap kinerja indikator-indikator moneter adalah mulai Januari 2007 hingga Desember 2011. Adapun penilaian indikatorindikator moneter dalam penelitian ini menggunakan perhitungan-perhitungan sebagai berikut.

BI Rate

Dalam melakukan penelitian ini, tingkat BI rate dihitung secara bulanan dari data pada lampiran 1 sehingga dapat dilihat kenaikan atau penurunan BI Rate tersebut dari periode ke periode, dapat diformulasikan sebagai berikut :

\section{$\mathrm{BI}$ Rate = BI Rate $\mathrm{t} / 12$}

Yaitu dimana:

$\mathrm{BI}$ Rate $\mathrm{t}=\mathrm{BI}$ Rate pada periode $\mathrm{t}$

Perubahan Indeks Harga Saham Gabungan

Dalam melakukan penelitian ini, tingkat pergerakan dan pertumbuhan Indeks Harga Saham Gabungan (IHSG) Bursa

\begin{abstract}
Efek Indonesia dihitung dalam suatu kenaikan atau penurunan IHSG tersebut dari periode ke periode yang terdapat pada lampiran 1, dapat diformulasikan sebagai berikut :
\end{abstract}




$$
\text { IHSG }=(\text { IHSG t-IHSGt-1)/IHSGt }
$$

Yaitu dimana:

$\begin{array}{ll}\text { IHSG } \mathrm{t} & =\mathrm{IHSG} \text { pada periode } \mathrm{t} \\ \text { IHSG } \mathrm{t}-1 & =\mathrm{IHSG} \text { pada periode } \mathrm{t}-1\end{array}$

Inflasi

Dalam melakukan penelitian ini, tingkat inflasi yang digunakan adalah tingkat inflasi yang dikeluarkan oleh Badan Pusat Statistik (BPS). Tingkat inflasi diukur dari perubahan Indeks Harga Konsumen (IHK) dengan menggunakan Indeks Laspeyres yang dimodifikasi. Dalam menghitung perubahan pada tingkat inflasi digunakan formulasi sebagai berikut:

$$
\mathrm{IHK}_{\mathrm{n}}=\frac{\sum\left(\mathrm{P}_{\mathrm{n}} / \mathrm{P}_{\mathrm{n}}-1\right) \mathrm{P}_{\mathrm{n}}-1 . \mathrm{Q}_{\mathrm{o}}}{\sum \mathrm{P}_{\mathrm{o}} \cdot \mathrm{Q}_{\mathrm{o}}} \times 100
$$

Yaitu dimana:

IHKn = Indeks Harga Konsumen pada akhir bulan ke-n

Pn = Harga barang konsumsi pada akhir bulan ke-n

Po = Harga barang pada periode dasar

Qo = Kuantitas pada periode dasar

Dalam melakukan pemilihan sampel digunakan metode purposive sampling yaitu dimana sampel yang dipilih dalam melakukan penelitian ini adalah sahamsaham sektor perbankan yang tercatat

pada Bursa Efek Indonesia dalam periode tahun 2007 - 2011. Pemilihan sampel didasarkan kepada tujuan dilaksanakannya penelitian dan pertimbangan-pertimbangan tertentu yaitu :

1. Sampel yang dipilih telah tercatat di BEI selama 5 tahun dan hingga kini masih tercatat dan diperdagangkan.

2. Ketersediaan data dan bahan-bahan pendukung mengenai sampel tersebut selama periode pengamatan. 
Sampel penelitian yang digunakan adalah saham perusahaan sektor perbankan yang masih tercatat dan aktif diperdagangkan di Bursa Efek Indonesia. Jumlah sampel di dalam sektor perbankan dapat dikatakan lebih sedikit jika dibandingkan dengan sektor industri lainnya di Bursa Efek Indonesia. Setelah melakukan pengumpulan sampel, data dan bahan pendukung lainnya untuk mendukung pelaksanaan penelitian ini maka akan dilakukan beberapa tahan lanjutan yaitu:

1. Seleksi dan pemilihan data Tahap dimana informasiinformasi yang telah dikumpulkan tersebut diseleksi dan dipilih untuk disesuaikan dengan masalah yang telah dirumuskan dan juga diharapkan untuk tercapainya tujuan penelitian ini.

2. Transformasi data

Tahap dimana data-data yang telah diseleksi, ditransformasikan dan dikelompokan sesuai pokokpokok permasalahan yang telah ditetapkan sehingga data-data tersebut siap untuk dihitung, diolah, dan dianalisis.

3. Penghitungan dan pengolahan data

Tahap dimana data-data tersebut akan diproses dengan melakukan perhitungan sesuai dengan formulasi yang tepat dengan menggunakan program Microsoft Excel. Hasil perhitungan yang diperoleh $t$

Hipotesis yang diajukan dalam penelitian ini adalah :

$\mathrm{H}_{1 \mathrm{a}}$ : $\mathrm{BI}$ rate berpengaruh negatif terhadap return saham sektor perbankan yang terdaftar di Bursa Efek Indonesia.

Inflasi merupakan faktor risiko yang harus dipertimbangkan dalam proses investasi. Adanya kenaikan harga secara umum akan berdampak pada berkurangnya daya beli sehingga tingkat hasil riil akan turun. Dengan demikian apabila inflasi naik, maka investor akan menginginkan kenaikan tingkat hasil nominal guna melindungi tingkat hasil riilnya.

$\mathrm{H}_{2 \mathrm{a}}$ : Inflasi berpengaruh negatif terhadap saham sektor perbankan yang terdaftar di Bursa Efek Indonesia. 
Membaiknya indikator ekonomi yang berarti respons positif dari pelaku pasar dapat dilihat dari Indeks harga Saham Gabungan (IHSG). Makin tinggi tingkat IHSG makin stabil perdagangan di Bursa Efek Indonesia. Gerakan naik turunnya Indeks Harga Saham Gabungan (IHSG) sangat sensitif terhadap perubahan harga saham, untuk

\section{HASIL DAN PEMBAHASAN}

Sektor industri perbankan merupakan sektor yang menarik untuk diteliti bagaimana pengaruh faktor-faktor BI Rate, inflasi dan IHSG tersebut terhadap return yang diterima karena pada sektor ini seperti kita ketahui bahwa industri perbankan indonesia juga memiliki rata-rata NIM yang lebih tinggi dibandingkan dengan perbankan di regionalnya sehingga menjadikan saham perbankan indonesia menarik karena dapat memperoleh marjin laba yang besar. Pertumbuhan ekonomi yang didorong oleh sektor konsumsi pada itu perubahan variabel IHSG sangat menarik untuk diteliti pengaruhnya terhadap return saham.

H3a : IHSG berpengaruh positif terhadap return saham sektor perbankan yang terdaftar di Bursa Efek Indonesia.

akhirnya dapat meningkatkan daya beli masyarakat yang akan meningkatkan pertumbuhan kredit pada sektor industri perbankan. Dengan demikian, kemampuan sektor perbankan untuk mencetak laba secara otomatis juga akan meningkat. Dengan alasan tersebut maka penelitian ini memakai data saham perbankan sebagai sampel penelitian. Daftar perusahaan yang akan digunakan dalam penelitian ini merupakan emiten yang berasal dari sektor industri perbankan yang terdaftar di Bursa Efek Indonesia untuk periode penelitian 2007 - 2011. 
Tabel 1 Daftar Saham Perbankan Periode 2007-2011

\begin{tabular}{cc} 
Kode & \\
Emiten & Nama Bank \\
BBCA & Bank Central Asia Tbk \\
BBNI & Bank Negara Indonesia \\
BBRI & Bank Rakyat Indonesia Tbk \\
BDMN & Bank Danamon Indonesia Tbk \\
BMRI & Bank Mandiri Tbk \\
BNLI & Bank Permata Tbk \\
BKSW & Bank Kesawan Tbk \\
BVIC & Bank Victoria Tbk \\
INPC & Bank Artha Graha Internasional Tbk \\
MEGA & Bank Mega Tbk \\
PNBN & Bank Panin Tbk \\
SDRA & Bank Himpunan Saudara 1906 Tbk \\
\hline
\end{tabular}

Saham yang memenuhi persyaratan adalah yang memiliki tingkat signifikansi kecil. Semakin kecil angka signifikansi, semakin baik tingkat signifikansi dari model tersebut. Parameter tingkat signifikansi adalah jika $\alpha<0,05$. Tingkat signifikansi menunjukkan seberapa baik suatu model telah diolah untuk dijadikan model penelitian. Setelah dilihat tingkat signifikansinya, dilihat juga angka $R$ - square, apakah cukup tinggi. Semakin tinggi nilai $R$-square nya, maka semakin baik model tersebut. Nilai $R$ square menunjukkan besarnya presentase suatu variabel bebas yang diolah dapat menjelaskan variabel terikatnya. Secara umum, faktor BI rate, inflasi dan IHSG hanya dapat menerangkan sebagian dari return saham yang diteliti. 
Tabel 2 Pengujian Multikolinearitas

\begin{tabular}{lcccccc} 
Emiten & \multicolumn{3}{c}{ Tolerance } & & VIF \\
& BI Rate & Inflasi & IHSG & BI Rate & Inflasi & IHSG \\
BBCA & 0,451 & 0,420 & 0,873 & 2,216 & 2,381 & 1,145 \\
BBNI & 0,451 & 0,420 & 0,873 & 2,216 & 2,381 & 1,145 \\
BBRI & 0,451 & 0,420 & 0,873 & 2,216 & 2,381 & 1,145 \\
BDMN & 0,451 & 0,420 & 0,873 & 2,216 & 2,381 & 1,145 \\
BMRI & 0,451 & 0,420 & 0,873 & 2,216 & 2,381 & 1,145 \\
BNLI & 0,451 & 0,420 & 0,873 & 2,216 & 2,381 & 1,145 \\
BKSW & 0,451 & 0,420 & 0,873 & 2,216 & 2,381 & 1,145 \\
BVIC & 0,451 & 0,420 & 0,873 & 2,216 & 2,381 & 1,145 \\
INPC & 0,451 & 0,420 & 0,873 & 2,216 & 2,381 & 1,145 \\
MEGA & 0,451 & 0,420 & 0,873 & 2,216 & 2,381 & 1,145 \\
PNBN & 0,451 & 0,420 & 0,873 & 2,216 & 2,381 & 1,145 \\
SDRA & 0,451 & 0,420 & 0,873 & 2,216 & 2,381 & 1,145 \\
\hline
\end{tabular}

Tabel 3 Pengujian Heteroskedastisitas dengan Uji White

\begin{tabular}{cc} 
Heteroskedasticity Test: & \\
White & Prob. Obs*R-quared \\
BDMN & 0,001 \\
BBNI & 0,003 \\
BBCA & 0,000 \\
BMRI & 0,345 \\
BNLI & 0,851 \\
BKSW & 0,003 \\
BVIC & 0,998 \\
BBRI & 0,081 \\
MEGA & 0,530 \\
PNBN & 0,866 \\
SDRA & 0,999 \\
INPC & 0,965 \\
\hline
\end{tabular}


Tabel 4 Summary Durbin-Watson

\begin{tabular}{cc} 
Emiten & Durbin Watson \\
BBCA & 2,172 \\
BBNI & 1,996 \\
BBRI & 2,310 \\
BDMN & 2,520 \\
BMRI & 2,247 \\
BNLI & 2,025 \\
BKSW & 2,511 \\
BVIC & 2,498 \\
INPC & 1,523 \\
MEGA & 2,152 \\
PNBN & 1,736 \\
SDRA & 2,065 \\
\hline
\end{tabular}

Dari tabel Summary Durbin-Watson saham perbankan selama periode 20072011 terlihat bahwa:

1) Tidak terjadi autokorelasi pada saham BBNI, BBCA, BMRI, BBRI, BNLI, MEGA, PNBN, dan SDRA.
2) Sedangkan pada saham BVIC, INPC, BDMN dan BKSW tidak dapat diambil kesimpulan.

Tabel 5 Hasil One-Sample Kolmogorov-Smirnov Test

$\begin{array}{cc}\text { Emiten } & \text { Asymp. Sig. (2-tailed) } \\ \text { BDMN } & 0,774 \\ \text { BBNI } & 0,519 \\ \text { BBCA } & 0,827 \\ \text { BMRI } & 0,219 \\ \text { BNLI } & 0,019 \\ \text { BKSW } & 0,154 \\ \text { BVIC } & 0,035 \\ \text { BBRI } & 0,591 \\ \end{array}$


Tabel 6 Hasil One-Sample Kolmogorov-Smirnov Test

\begin{tabular}{lc} 
Emiten & $\begin{array}{c}\text { Asymp. } \\
\text { (2-tailed) }\end{array}$ \\
& 0,000 \\
INPC & 0,247 \\
MEGA & 0,826 \\
PNBN & 0,012 \\
SDRA & \\
\hline
\end{tabular}

Setelah dilakukan uji normalitas dengan menggunakan uji Kolmogorov-Smirnov ternyata angka signifikansinya di bawah 0.05 sehingga tidak memenuhi asumsi normalitas menurut uji KolmogorovSmirnov. Namun menurut Brook (2008) masalah normalitas dapat diatasi dengan penggunaan jumlah data sampel penelitian di atas 30. Data penelitian ini berjumlah 60 sampel dan diasumsikan sudah memenuhi asumsi normalitas sehingga model regresi sudah

memenuhi asumsi normalitas. Berikut adalah tabel yang merupakan hasil regresi dari penelitian dengan menggunakan data SPSS yang ada pada lampiran 4 menunjukkan pengaruh dari setiap variabel independen yaitu BI rate, inflasi dan IHSG terhadap variabel dependen yaitu return saham sektor perbankan yang terdiri dari saham BDMN, BBNI, BBCA, BNLI, BKSW, BVIC, BBRI, BMRI, INPC, MEGA, PNBN dan SDRA. Dari hasil regresi pada tabel tersebut dapat dilihat signifikansi dari pengaruh hubungan variabel independen terhadap variabel dependen yang mencerminkan seberapa besar variasi variabel independen menjelaskan variabel dependen yang dianalisis dengan uji hipotesis dan koefisien determinasi. 
Tabel 7 Hasil Regresi Lanjutan

\begin{tabular}{|c|c|c|c|c|c|c|c|c|c|}
\hline & $\mathrm{BN}$ & & & & SW & & BI & IC & \\
\hline & $\begin{array}{c}\text { Unstandardized } \\
\text { Coefficients } \\
\text { B }\end{array}$ & $\begin{array}{c}\mathbf{t}- \\
\text { Statistic }\end{array}$ & Sig. & $\begin{array}{c}\text { Unstandardized } \\
\text { Coefficients } \\
\text { B }\end{array}$ & $\begin{array}{c}\mathrm{t}- \\
\text { Statistic }\end{array}$ & Sig. & $\begin{array}{c}\text { Unstandardized } \\
\text { Coefficients } \\
\text { B }\end{array}$ & $\begin{array}{c}\mathrm{t}- \\
\text { Statistic }\end{array}$ & Sig. \\
\hline (constant) & 0,105 & 0,985 & 0,329 & $-0,028$ & $-0,265$ & 0,792 & $-0,262$ & $-1,473$ & 0,146 \\
\hline BI Rate & 16,497 & 0,759 & 0,451 & 8,619 & 0,400 & 0,690 & 64,644 & 1,783 & 0,080 \\
\hline Inflasi & 0,124 & 0,013 & 0,990 & $-2,056$ & $-0,220$ & 0,827 & $-24,607$ & $-1,563$ & 0,124 \\
\hline IHSG & 0,845 & 4,755 & 0,000 & $-0,191$ & $-1,084$ & 0,283 & 0,545 & 1,840 & 0,071 \\
\hline $\mathrm{R}$-squared & \multicolumn{3}{|c|}{0,350} & \multicolumn{3}{|c|}{0,027} & \multicolumn{3}{|c|}{0,126} \\
\hline $\begin{array}{l}\text { Prob(F- } \\
\text { statistic) }\end{array}$ & \multicolumn{3}{|c|}{0,000} & \multicolumn{3}{|c|}{0,666} & \multicolumn{3}{|c|}{0,050} \\
\hline
\end{tabular}

Tabel 8 Hasil Regresi Lanjutan

\begin{tabular}{|c|c|c|c|c|c|c|c|c|c|}
\hline & \multicolumn{3}{|c|}{ BBRI } & \multicolumn{3}{|c|}{ BMRI } & \multicolumn{3}{|c|}{ INPC } \\
\hline & $\begin{array}{l}\text { Unstandardized } \\
\text { Coefficients } \\
\text { B }\end{array}$ & t-Statistic & Sig. & $\begin{array}{l}\text { Unstandardized } \\
\text { Coefficients } \\
\text { B }\end{array}$ & $\begin{array}{c}\text { t- } \\
\text { Statistic }\end{array}$ & Sig. & $\begin{array}{l}\text { Unstandardized } \\
\text { Coefficients } \\
\text { B }\end{array}$ & $\begin{array}{c}\text { t- } \\
\text { Statistic }\end{array}$ & Sig. \\
\hline (constant) & 0,020 & 0,268 & 0,789 & $-0,024$ & $-0,336$ & 0,738 & $-1,163$ & $-2,122$ & 0,038 \\
\hline BI Rate & 4,583 & $-0,305$ & 0,761 & $-3,453$ & $-0,240$ & 0,811 & 281,488 & 2,517 & 0,015 \\
\hline Inflasi & 10,317 & 1,583 & 0,119 & 8,968 & 1,433 & 0,157 & $-100,153$ & $-2,062$ & 0,044 \\
\hline IHSG & 1,272 & 10,369 & 0,000 & 1,433 & 12,161 & 0,000 & 0,079 & 0,086 & 0,932 \\
\hline R-squared & & 0,664 & & & 735 & & 0,1 & & \\
\hline $\begin{array}{l}\text { Prob(F- } \\
\text { statistic) }\end{array}$ & & 0,000 & & & 000 & & 0,1 & & \\
\hline
\end{tabular}

Tabel 9 Hasil Regresi Lanjutan

\begin{tabular}{|c|c|c|c|c|c|c|c|c|c|}
\hline & \multicolumn{3}{|c|}{ MEGA } & \multicolumn{3}{|c|}{ PNBN } & \multicolumn{3}{|c|}{ SDRA } \\
\hline & $\begin{array}{l}\text { Unstandardize } \\
\text { d Coefficients } \\
\text { B }\end{array}$ & $\begin{array}{c}\text { t- } \\
\text { Statisti } \\
\text { c }\end{array}$ & Sig. & $\begin{array}{l}\text { Unstandardize } \\
\text { d Coefficients } \\
\text { B }\end{array}$ & $\begin{array}{c}\text { t- } \\
\text { Statisti } \\
\text { c }\end{array}$ & Sig. & $\begin{array}{l}\text { Unstandardize } \\
\text { d Coefficients } \\
\text { B }\end{array}$ & $\begin{array}{c}\text { t- } \\
\text { Statisti } \\
\text { c }\end{array}$ & Sig. \\
\hline (constant) & $-0,074$ & $-0,043$ & 0,660 & 0,004 & 0,037 & 0,970 & 0,094 & 0,404 & 0,688 \\
\hline BI Rate & 8,310 & 0,243 & 0,809 & $-10,151$ & $-0,486$ & 0,629 & 4,330 & 0,091 & 0,928 \\
\hline Inflasi & 7,633 & 0,513 & 0,610 & 10,367 & 1,143 & 0,258 & $-20,900$ & $-1,011$ & 0,316 \\
\hline IHSG & $-0,092$ & $-0,327$ & 0,745 & 1,030 & 6,028 & 0,000 & 1,010 & 2,597 & 0,012 \\
\hline R-squared & \multicolumn{3}{|c|}{0,027} & \multicolumn{3}{|c|}{0,402} & \multicolumn{3}{|c|}{0,186} \\
\hline $\begin{array}{l}\text { Prob(F- } \\
\text { statistic) }\end{array}$ & \multicolumn{3}{|c|}{0,670} & \multicolumn{3}{|c|}{0,000} & \multicolumn{3}{|c|}{0,009} \\
\hline
\end{tabular}


Analisis Koefisien Determinasi

Uji koefisien determinasi adalah untuk mengukur seberapa jauh kemampuan model dalam menerangkan variasi variabel independen. Nilai koefisien determinasi adalah antara nol dan satu. Nilai $\mathrm{R}_{2}$ yang kecil berarti kemampuan setiap variabel independen dalam menjelaskan variabel dependen sangat terbatas. Nilai yang mendekati satu berarti variabel variabel independen memberikan hampir semua informasi yang dibutuhkan untuk memprediksi variabel dependen. Dari tabel regresi penelitian terlihat nilai $\mathrm{R}_{2}$ untuk model regresi saham BDMN adalah sebesar 0,398 yang artinya bahwa kemampuan variabel independen yaitu BI rate, inflasi dan IHSG dalam model regresi saham BDMN mampu menjelaskan perubahan return saham sebesar 39,8 $\%$, sedangkan sisanya sebesar $60,2 \%$ dijelaskan oleh faktor-faktor lain yang tidak dimasukkan ke dalam model penelitian. Namun ketika variabel BI rate, inflasi dan IHSG dimasukkan ke dalam model saham BBNI dapat memperlihatkan nilai $R_{2}$ sebesar 0,607 yang artinya bahwa kemampuan variabel independen dalam model saham BBNI mampu menjelaskan return saham perusahaan sebesar $60,7 \%$, sedangkan sisanya sebesar $39,3 \%$ dijelaskan oleh faktor-faktor lain yang tidak dimasukkan ke dalam model penelitian. Berbeda dengan model regresi saham BBCA dimana variabel independen BI rate, inflasi dan IHSG yang memberikan nilai $R_{2}$ hanya sebesar 0,379 yang artinya kemampuan variabel independen dalam model regresi saham BBCA mampu menjelaskan return saham perusahaan sebesar 37,9\%, sedangkan sisanya sebesar $62,1 \%$ dijelaskan oleh faktorfaktor lain yang tidak dimasukkan ke dalam model penelitian. Namun ketika variabel BI rate, inflasi dan IHSG dimasukkan ke dalam model regresi saham BNLI dapat memperlihatkan nilai R2 sebesar 0,350 yang artinya bahwa kemampuan variabel independen dalam model saham BNLI mampu menjelaskan return saham perusahaan sebesar 35\%, sedangkan sisanya sebesar $65 \%$ dijelaskan oleh faktor-faktor lain yang tidak dimasukkan ke dalam model penelitian. Ketika model regresi saham BKSW dilakukan variabel independen $\mathrm{BI}$ rate, inflasi dan IHSG memberikan nilai R2 hanya sebesar 0,027 yang artinya kemampuan variabel 
independen dalam model regresi saham BKSW mampu menjelaskan return saham perusahaan sebesar 2,7\%, sedangkan sisanya sebesar $97,3 \%$ dijelaskan oleh faktor-faktor lain yang tidak dimasukkan ke dalam model penelitian. Namun ketika variabel BI rate, inflasi dan IHSG dimasukkan ke dalam model regresi saham BVIC dapat memperlihatkan nilai R2 sebesar 0,126 yang artinya bahwa kemampuan variabel independen dalam model saham BVIC mampu menjelaskan return saham perusahaan sebesar $12,6 \%$, sedangkan sisanya sebesar $87,4 \%$ dijelaskan oleh faktor-faktor lain yang tidak dimasukkan ke dalam model penelitian. Hasil model regresi saham BBRI dimana variabel independen BI rate, inflasi dan IHSG yang memberikan nilai R2 hanya sebesar 0,664 yang artinya kemampuan variabel independen dalam model regresi saham BBRI mampu menjelaskan return saham perusahaan sebesar $66,4 \%$, sedangkan sisanya sebesar $33,6 \%$ dijelaskan oleh faktor-faktor lain yang tidak dimasukkan ke dalam model penelitian. Namun ketika variabel BI rate, inflasi dan IHSG dimasukkan ke dalam model regresi saham BMRI dapat memperlihatkan nilai $\mathrm{R}_{2}$ sebesar 0,735 yang artinya bahwa kemampuan variabel independen dalam model saham BVIC mampu menjelaskan return saham perusahaan sebesar $73,5 \%$, sedangkan sisanya sebesar $26,5 \%$ dijelaskan oleh faktor-faktor lain yang tidak dimasukkan ke dalam model penelitian. Begitu pula dari hasil model regresi saham INPC dimana variabel independen BI rate, inflasi dan IHSG yang memberikan nilai R2 hanya sebesar 0,105 yang artinya kemampuan variabel independen dalam model regresi saham INPC mampu menjelaskan return saham perusahaan sebesar 10,5\%, sedangkan sisanya sebesar $89,5 \%$ dijelaskan oleh faktorfaktor lain yang tidak dimasukkan ke dalam model penelitian. Namun ketika variabel BI rate, inflasi dan IHSG dimasukkan ke dalam model regresi saham MEGA dapat memperlihatkan nilai $R_{2}$ sebesar 0,027 yang artinya bahwa kemampuan variabel independen dalam model saham MEGA mampu menjelaskan return saham perusahaan sebesar $2,7 \%$, sedangkan sisanya sebesar 97,3\% dijelaskan oleh faktorfaktor lain yang tidak dimasukkan ke dalam model penelitian. Hasil model regresi saham PNBN dimana variabel independen BI rate, inflasi dan IHSG 
yang memberikan nilai $\mathrm{R}_{2}$ hanya sebesar 0,402 yang artinya kemampuan variabel independen dalam model regresi saham PNBN mampu menjelaskan return saham perusahaan sebesar 40,2\%, sedangkan sisanya sebesar $59,8 \%$ dijelaskan oleh faktorfaktor lain yang tidak dimasukkan ke dalam model penelitian. Kemudian ketika variabel $\mathrm{BI}$ rate, inflasi dan IHSG dimasukkan ke dalam model regresi saham SDRA dapat memperlihatkan nilai $\mathrm{R}_{2}$ sebesar 0,186 yang artinya bahwa kemampuan variabel independen dalam model saham SDRA mampu menjelaskan return saham perusahaan sebesar $18,6 \%$, sedangkan sisanya sebesar $81,4 \%$ dijelaskan oleh faktor-faktor lain yang tidak dimasukkan ke dalam model penelitian. Dengan demikian diantara emiten sektor perbankan yang digunakan dalam penelitian ini dapat menunjukkan model saham BBNI dengan nilai $\mathrm{R}_{2} \quad 60,7 \%$ merupakan saham yang memiliki nilai tertinggi dan dikatakan mampu menjelaskan perubahan variabel dependen yaitu return saham daripada model saham lainnya. Sedangkan saham MEGA memiliki nilai $\mathrm{R}_{2}$ terendah yaitu $2,7 \%$ dan tidak mampu menjelaskan model penelitian ini dibandingkan model saham lainnya.

\section{Uji Statistik F}

Uji ini digunakan untuk menguji pengaruh variabel independen secara bersama-sama terhadap variabel dependen. Uji F ini direpresentasikan melalui nilai probabilitas dari $F$ statistic. Apabila nilai probabilitas dari F hitung kurang dari 0,05 maka hipotesis yang menyatakan bahwa terdapat pengaruh yang signifikan antara beberapa variabel independen terhadap variabel dependen diterima. Berdasarkan data tabel model regresi hasil pengujian untuk saham BBNI, BBCA, BBRI, BDMN, BNLI, BMRI, BVIC, PNBN dan SDRA dengan variabel independen yaitu $\mathrm{BI}$ rate, inflasi dan IHSG menunjukkan nilai probabilitas dari $\mathrm{F}$ hitung kurang dari 0,05 yang memberikan gambaran bahwa terdapat pengaruh yang signifikan variabel independen terhadap return saham BBNI, BBCA, BBRI, BDMN, BNLI, BMRI, BVIC, PNBN dan SDRA. Sedangkan hasil pengujian untuk saham dengan variabel independen yaitu BI rate, inflasi dan IHSG menunjukkan nilai probabilitas dari $\mathrm{F}$ hitung lebih dari 0,05 yang menunjukkan bahwa saham BKSW, 
INPC dan MEGA sudah memberikan gambaran bahwa tidak terdapat pengaruh yang signifikan variabel independen terhadap return saham BKSW, INPC dan MEGA. Hasil pengujian multivariate pada lampiran 5 juga menunjukkan hasil penelitian ini bahwa variabel IHSG merupakan variabel yang paling berpengaruh dengan signifikasi di bawah $\alpha=5 \%$, terhadap return saham perbankan secara keseluruhan sedangkan $\mathrm{BI}$ rate dan inflasi tidak mempengaruhi return saham perbankan pada periode penelitian ini yaitu 2007-2011.

\section{Analisis Hasil Pengujian Hipotesis}

Model regresi yang baik adalah setelah melewati uji asumsi klasik yaitu uji normalitas, uji multikolinearitas, dan uji heteroskedastisitas yang membuktikan bahwa model regresi layak digunakan untuk uji hipotesis dengan melihat signifikansi regresi yang didapat. Dari hasil regresi yang telah didapatkan dari pengolahan data SPSS dan Eviews, maka selanjutnya dilakukan analisis atas hasil pengujian hipotesis dengan menggunakan tabel yang diolah penulis dari hasil regresi.
Pengaruh BI rate terhadap return saham perbankan

Pengujian hipotesis pertama adalah menguji tentang pengaruh $\mathrm{BI}$ rate terhadap return saham perbankan. Dari tabel hasil regresi untuk model return saham perbankan didapat bahwa variabel $\mathrm{BI}$ rate berpengaruh positif terhadap satu return saham perbankan yaitu return saham INPC dengan tingkat signifikansi di bawah $\alpha=5 \%$, artinya BI Rate berpengaruh terhadap return saham dengan tingkat keyakinan $95 \%$. Sedangkan terhadap return saham perbankan lainnya yaitu BBCA, BDMN, BBRI, BMRI, BVIC, PNBN, BBNI, BNLI, INPC, MEGA, dan SDRA variabel BI rate memiliki tingkat signifikansi di atas $\alpha=5 \%$, artinya BI rate berpengaruh negatif terhadap return saham perbankan dengan demikian $\mathrm{H}_{\mathrm{a} 1}$ tidak diterima karena $\mathrm{BI}$ rate memiliki pengaruh positif terhadap saham INPC. Hasil penelitian ini sesuai dengan hasil penelitian terdahulu yang dilakukan oleh Bernanke (2004) yang menyatakan bahwa suku bunga bank sentral berpengaruh positif dengan return saham, namun pada periode penelitian ini yaitu 2007 - 2008 terjadi krisis subprime mortgage dimana juga menyebabkan terjadinya abnormal 
return pada saham sektor perbankan. Namun hal ini bertentangan dengan penelitian Beirne (2009) dimana suku bunga bank sentral tidak mempengaruhi saham sektor perbankan dan dapat disebabkan oleh pasar modal industri Hal ini memperlihatkan bahwa kondisi Bursa Efek Indonesia (BEI) merupakan contoh pasar yang belum efisien sehingga masih banyak variabel lain yang mempengaruhi kinerja return saham dan hal ini dapat diterima menurut penelitian Bia (2005) regresi yang baik adalah setelah melewati uji asumsi klasik yaitu uji normalitas, uji multikolinearitas, dan uji heteroskedastisitas yang membuktikan bahwa model regresi layak digunakan untuk uji hipotesis dengan melihat signifikansi regresi yang didapat. Dari hasil regresi yang telah didapatkan dari pengolahan data SPSS dan Eviews, maka selanjutnya dilakukan analisis atas hasil pengujian hipotesis dengan menggunakan tabel yang diolah penulis dari hasil regresi.

Pengaruh Inflasi terhadap return saham perbankan

Pengujian hipotesis kedua adalah menguji tentang pengaruh inflasi terhadap return saham perbankan. Dari tabel hasil regresi untuk model return saham perbankan didapat bahwa variabel inflasi hanya berpengaruh positif terhadap return saham perbankan yaitu return saham INPC dengan tingkat signifikansi di bawah $\alpha$ $=5 \%$ dan tingkat keyakinan $95 \%$. Sedangkan terhadap return saham BBCA, BDMN, BBRI, BMRI, BVIC, PNBN, BBNI, BNLI, INPC, MEGA, dan SDRA variabel inflasi tidak berpengaruh karena tidak signifikan, sehingga tidak dapat dikatakan bahwa saham pada sektor perbankan periode 2007 - 2011 dipengaruhi oleh inflasi karena variabel inflasi hanya mempengaruhi satu saham saja dan hasil ini mendukung beberapa penelitian sebelumnya yang telah meneliti tentang relevansi inflasi terhadap return saham perusahaan. Dimulai dari penelitian yang dilakukan oleh Boucher (2006) dimana inflasi tidak berpengaruh positif terhadap return saham yang dilakukan atas saham dalam indeks Standard \& Poor's selain itu penelitian Anna (2005) juga tidak menunjukkan adanya relevansi terhadap return saham sektor hotel dan pariwisata dan didukung dengan penelitian Bagus (2009) yang menunjukkan inflasi tidak berpengaruh terhadap return saham. 
Hasil ini menunjukkan hipotesis $\mathrm{H}_{\mathrm{a} 2}$ tidak diterima.hipotesis pertama adalah menguji tentang pengaruh $\mathrm{BI}$ rate terhadap return saham perbankan. Dari tabel hasil regresi untuk model:

Pengaruh IHSG terhadap return saham perbankan

Pengujian hipotesis ketiga adalah menguji tentang pengaruh IHSG terhadap return saham perbankan. Dari tabel hasil regresi untuk model return saham perbankan menunjukkan bahwa variabel IHSG berpengaruh terhadap return saham perbankan yaitu return saham BBCA, BDMN, BMRI, BBRI, PNBN, BBNI, BNLI, dan SDRA dengan hubungan positif dengan tingkat signifikansi di bawah $\alpha=5 \%$, artinya IHSG berpengaruh positif terhadap return saham dengan tingkat keyakinan

\section{KESIMPULAN}

Penelitian ini pada dasarnya ingin melihat apakah terdapat pengaruh BI rate, inflasi serta IHSG terhadap return saham perbankan. Setelah dilakukan penelitian dengan menggunakan BI rate, inflasi serta IHSG sebagai variabel independen dan return saham-saham sektor perbankan sebagai variabel
95\%. Sedangkan terhadap return saham BVIC, BKSW, INPC, dan MEGA perubahan IHSG tidak berpengaruh karena tidak signifikan. Hal ini bisa saja disebabkan karena saham tersebut tidak laku, atau saham "gorengan" dan bisa saja disebabkan karena adanya regulasi Bank Indonesia mengenai kepemilikan tunggal (single presence policy) yang terbit pada tahun 2008 sehingga membatasi minat investor asing untuk membeli saham perbankan. Karena sebagian besar investor di Bursa Efek Indonesia adalah investor asing. Dengan demikian dapat dikatakan IHSG mempengaruhi sebagian besar saham sektor perbankan periode 2007 - 2011 dalam penelitian ini sehingga $\mathrm{H}_{\mathrm{a} 3}$ diterima.

dependen, maka dapat diambil kesimpulan sebagai berikut:

1. $\mathrm{BI}$ rate tidak berpengaruh signifikan terhadap return saham perbankan periode 2007 - 2011 karena hanya berpengaruh terhadap satu saham yaitu INPC. Dengan demikian, dapat disimpulkan bahwa variabel BI rate, tidak 
akan mempengaruhi tinggi rendahnya return saham sektor perbankan.

2. Inflasi tidak berpengaruh signifikan terhadap return saham perbankan periode 2007 - 2011 karena hanya berpengaruh terhadap satu saham yaitu INPC. Dengan demikian, dapat disimpulkan bahwa variabel inflasi, tidak akan mempengaruhi tinggi rendahnya return saham sektor perbankan

3. IHSG berpengaruh signifikan terhadap return saham perbankan periode 2007 - 2011 yaitu return saham BBNI, BBCA, BDMN, BMRI, PNBN, BBRI, BNLI, dan SDRA. Dengan demikian, dapat disimpulkan bahwa adanya perubahan IHSG, maka akan mempengaruhi tinggi rendahnya return saham tersebut.

4. IHSG merupakan variabel yang berpengaruh positif terhadap return saham perbankan periode 2007 2011 dibandingkan dengan
BI rate dan inflasi. Dengan demikian, dapat disimpulkan bahwa dengan adanya perubahan IHSG maka akan lebih mempengaruhi tinggi rendahnya return saham sektor perbankan dibandingkan dengan $\mathrm{BI}$ rate dan inflasi.

5. Dari 12 saham sektor perbankan yang diteliti, secara simultan BI rate, inflasi dan IHSG berpengaruh signifikan terhadap return 9 saham perbankan periode 2007 2011 terutama untuk saham BBCA, BBNI, BDMN, BMRI, BBRI, BKSW, BNLI, PNBN dan SDRA sehingga dengan demikian perubahan return sahamsaham tersebut dipengaruhi oleh indikator moneter yang telah ditentukan yaitu BI rate, inflasi, dan IHSG. Sedangkan return 3 saham lainnya yaitu BKSW, INPC dan MEGA tidak dipengaruhi secara signifikan oleh indikator moneter yang ditentukan. 


\section{DAFTAR PUSTAKA}

Adiwarman, K., (2008). Mengantisipasi dampak krisis keuangan global.

Anoraga, P.dan Pakarti, P.

(2008).Pengantar Pasar Modal. Jakarta : Rineka Cipta.

Badan Pengawas Pasar Modal (2003), Panduan investasi di pasar modal Indonesia.

Bank Indonesia , Laporan tahunan Bank Indonesia 2011.

Beirne, John., Caporale, Spagnolo. (2009). Market, interest rate and exchange risk effects on financial stock returns, QASS, Vol.3 (2), 2009,44-68.

Bernanke, Ben S., \& Kuttner, Kenneth. (2004). What explains the stock market's reaction to federal reserve policy.

Bodie, Zvi, Kane, Alex, \& Marcus, Alan J. (2011). Investment. 9th Edition. Singapore :McGrawHill.

Boucher, Christophe. (2006). Stock prices, inflation and stock returns predictability.

Brook, Chris. (2008). Introductory econometrics for finance. New York : Cambridge University Press.
Bruce J. Feibel. (2003). Investment performance measurement. New York, N.Y (J): John Wiley $\&$ Sons Inc.

Bursa Efek Indonesia (2010), Buku panduan Indeks Harga Saham Bursa Efek Indonesia.

Damodaran, Aswath. (2002). Investment valuation: Tools and techniques for determining the value of any asset, 2nd Edition. John Willey \& Sons, Inc.

Darmadji, T., dan Fakhruddin ,J.M. (2001). Pasar Modal Di Indonesia: Pendekatan Tanya Jawab. Jakarta: Salemba Empat.

Eko P. Pratomo \& Ubaidillah Nugraha. (2005). Reksa Dana, Solusi perencanaan investasi di era modern. Jakarta: PT. Gramedia Pustaka Utama.

Emmanuel, E.D. dan Samuel, O.A. (2009). An impact analysis of real gross domestic product inflation and interest rates on stock prices of quotedcompanies in Nigeria. International Research Journal of Finance and Economics.

Fama, Eugene F., French, Kenneth R.

(1981). Stock returns, real activity, inflation and money, American Economic Review.

Iqbal, Haider. Arbitrage Pricing Theory: Evidence from stock market, April 2005. 
Jogiyanto,H. (2003). Teori Portofolio dan Analisis Investasi. Yogyakarta: BPFE.

Jones, C. P., (2009), Investment Analysis and Management, 11th Edition, New York, N. Y (J): John Wiley \& Sons, Inc

Manurung, Adler Haymans dan Nugroho. (2005). Pengaruh variabel makro terhadap hubungan "Conditional mean and conditional volatility" IHSG. Jurnal Usahawan No.06 TH XXXIV Juni 2005.

Mishkin, F. S. (2004). The Economics of Money, Banking, and Financial Boston: AddisonWesley.

Mohammad, S.D., Hussain, A. dan Ali,
A. (2009). Impact of macroeconomics variables on stock prices: emperical evidence in case of KSE.European Journal of Scientific Research, Vol. 38, No. 1, pp. 96-103.

Montagnoli, A, Kontonikas dan

Spagnolo, N. (2006). Stock returns and inflation: The impact of inflation targeting.

Mousa, Shukairi Noti., Waleed,

Hasoneh. (2006). The relationship between inflation and stock prices. IJRRAS, Vol 10, No.1

Ross, S.A., Westerfield, R.W., dan
Jaffe,J. (2010). Corporate Finance (9th edition).New York : McGraw-Hill.

Weston, J.F., dan Brigham, E.F. (2008). Dasar-Dasar Manajemen keuangan. Jakarta: Penerbit Erlangga.

Wignall, A.B., dan Atkinson, P. (2008). The current financial crisis: causes and policy issues

World Bank. (2010). Indonesia Economic Quarterly: Continuity amidst Volatility. Jakarta: World Bank

Yamin, Sofyan, Rachmah, Lien A., \& Kurniawan, Heri. (2011). Regresi dan korelasi dalam genggaman anda. Jakarta : Salemba 